\title{
Congenital malformations in the neonatal unit of Arifin Achmad Hospital, Pekanbaru: occurrence and trends
}

\author{
Dewi Anggraini Wisnumurti
}

\begin{abstract}
Background Congenital malformations are a global and continual issue, contributing to neonatal mortality. The incidence and prevalence, as well as distribution of congenital malformations vary among countries.

Objective To determine the 'prevalence, distribution, and trends in congenital malformations which are important to develop plans to cope with the problem.

Methods We reviewed all cases of congenital malformations admitted to the Neonatal Unit, Department of Child Health, Arifin Ahmad Hospital from 2008 to 2010. Data were collected from medical records. Diagnoses of congenital malformations were established by history-taking, physical examination, and specific laboratory tests. Trends in the distribution of congenital malformation types, as well as clinical outcomes were highlighted.

Results During the study period there were 2,317 infants admitted to the Neonatal Unit, 724 in 2008, 772 in 2009, and 821 in 2010. Most patients were referred by other hospitals, at the age of $0-3$ days. Most patients had normal birth weight and were delivered vaginally. Of the 2,317 infants, 302 were diagnosed with congenital malformations; the most common congenital malformations were of the digestive tract. The distribution of anomaly types was relatively constant over time, but the proportion of patients with congenital malformations discharged alive increased in the latter two years of the 3-year period studied.

Conclusion Most infants in our study had congenital malformations involving the gastrointestinal tract. Distribution trends were constant over time. Further efforts should be made to better manage future cases. [Paediatr Indones. 2012;52:284-8].
\end{abstract}

Keywords: congenital malformation, neonate

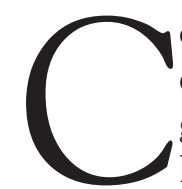
ongenital malformations are structural defects resulting from abnormal embryogenesis. ${ }^{1}$ Anomalies range from mild, with little or no effect on an infant's life, to fatal. The overall occurrence of congenital malformations is reported to be roughly $3 \%$ of all live births. ${ }^{1,2}$ However, occurrences vary among regions and countries, reflecting differences in the complex interaction of genetic and environmental factors, as a function of time, race, and geographic location. There are also differences in the spectrum of types of malformations. Congenital malformations have become one of the most important health problems both in developed and developing countries. Congenital malformations requiring urgent medical intervention was reported to be less than $1 \%{ }^{3}$

The etiology and risk factors for congenital malformation include consanguinity, maternal exposure to toxic substances during pregnancy, infections, and malnutrition. ${ }^{2}$ Early diagnosis and prompt treatment of congenital malformations are needed for improved prognosis. Arifin Ahmad Hospital, the largest hospital in the province, serves as the province's secondary referral hospital. Infants

From the Department of Child Health, Riau University Medical School, Arifin Achmad Hospital, Pekanbaru, Indonesia

Reprint requests to: Dewi Anggraini Wisnumurti, MD, Department of Child Health, Riau University Medical School, Arifin Achmad Hospital, Pekanbaru, Indonesia. E-mail: dewirobinar@yahoo.com 
with congenital malformations are among those referred by other hospitals, some of whom require surgical intervention. Congenital malformations ranked second in reasons for referral, after perinatal problems. This study was performed to review the congenital malformations in infants admitted to the Neonatal Unit during 2008-2010, and to evaluate trends in these conditions over the 3-year period.

\section{Methods}

In this retrospective study, we collected data from medical records of patients in the Neonatal and Fetomaternal Units from 2008 to 2010. We collected data including sex, age at admission, birth weight, method of delivery, length of hospitalization and payment method. Diagnoses of congenital malformations were established by history-taking, physical examination, and relevant tests. We classified the congenital malformations according to the International Statistical Classification of Diseases and Related Health Problems (Revised ICD-10 2007). ${ }^{4}$ Here we describe the data and trends in malformation types over the 3-year time period.

\section{Results}

During the study period there were 2,317 infants admitted to the neonatal unit, 724 in 2008, 772 in 2009, and 821 in 2010. Of these patients, 302 infants were diagnosed with congenital malformations. As shown in Table 1, the numbers of infants with congenital malformations per year were 92 in 2008, 95 in 2009, and 115 in 2010. We found that most congenital malformations were of the digestive tract, and males outnumbered females. Most patients with congenital digestive malformations (malformation of anorectum) and birth weights of 2500 4000 grams, and most were delivered vaginally. The types and percentages of congenital malformations are depicted in Table 1, while the complete characteristics of the infants are shown in Table 2.

Table 1. Congenital malformations diagnosed according to the Revised ICD-10 $2007^{4}$

\begin{tabular}{|c|c|c|c|c|}
\hline \multirow{2}{*}{\multicolumn{2}{|c|}{ Diagnosis }} & \multirow{2}{*}{$\begin{array}{l}2008 \\
\mathrm{n}(\%)\end{array}$} & \multirow{2}{*}{$\begin{array}{l}2009 \\
\mathrm{n}(\%) \\
\end{array}$} & \multirow{2}{*}{$\begin{array}{l}2010 \\
\mathrm{n}(\%)\end{array}$} \\
\hline & & & & \\
\hline Q00.0 & Anencephaly & $0(0)$ & $0(0)$ & $2(2)$ \\
\hline Q01 & Encephalocele & $4(4)$ & $4(4)$ & $7(6)$ \\
\hline Q03 & Hydrocephalus & $10(11)$ & $9(10)$ & $4(4)$ \\
\hline Q21 & Cardiac septal malformation & $6(7)$ & $2(2)$ & $3(3)$ \\
\hline Q24.0 & Dextrocardia & $1(1)$ & $0(0)$ & $0(0)$ \\
\hline Q25 & Malformation of great arteries & $1(1)$ & $1(1)$ & $0(0)$ \\
\hline Q35.1 & Palatoschisis & $1(1)$ & $2(2)$ & $2(2)$ \\
\hline Q37.4 & Labiognatopalatoschisis & $7(8)$ & $13(14)$ & $15(13)$ \\
\hline Q39.0 & Atresia of oesophagus & $0(0)$ & $1(1)$ & $0(0)$ \\
\hline Q40.0 & Hypertrophic pyloric stenosis & $0(0)$ & $1(1)$ & $0(0)$ \\
\hline Q41.0 & Stenosis of small intestine & $1(1)$ & $0(0)$ & $0(0)$ \\
\hline Q42.9 & Malformation of anorectum & $21(23)$ & $20(21)$ & $30(26)$ \\
\hline Q43.1 & Hirschsprung's disease & $7(8)$ & $9(10)$ & $23(20)$ \\
\hline Q52.4 & Vaginal tumor & $0(0)$ & $0(0)$ & $1(1)$ \\
\hline Q61 & Polycystic kidney & $0(0)$ & $0(0)$ & $1(1)$ \\
\hline Q79.0 & Diaphragmatic hernia & $3(3)$ & $5(5)$ & $3(3)$ \\
\hline Q79.1 & Eventration of diaphragm & $1(1)$ & $0(0)$ & $0(0)$ \\
\hline Q79.2 & Omphalocele & $5(5)$ & $5(5)$ & $3(3)$ \\
\hline Q79.3 & Gastroschisis & $10(11)$ & $7(7)$ & $7(6)$ \\
\hline Q80.2 & Collodion (Lamellar ichthyosis) & $1(1)$ & $0(0)$ & $0(0)$ \\
\hline Q87.0 & Pierre Robin syndrome & $1(1)$ & $0(0)$ & $1(1)$ \\
\hline Q89.2 & Hyperplasia of thymus & $1(1)$ & $0(0)$ & $0(0)$ \\
\hline Q89.7 & Multiple congenital malformations & $7(8)$ & $11(12)$ & $9(8)$ \\
\hline Q89.8 & Teratoma & $2(2)$ & $0(0)$ & $0(0)$ \\
\hline \multirow[t]{2}{*}{ Q90 } & Down syndrome & $2(2)$ & $5(5)$ & $4(4)$ \\
\hline & Total & 92 & 95 & 115 \\
\hline
\end{tabular}


Dewi Anggraini Wisnumurti et al: Congenital malformations in the neonatal unit of Arifin Achmad Hospital, Pekanbaru

Table 2.Characteristics of infants with congenital malformations admitted to the Neonatal Unit, Arifin Achmad Hospital, 2008-2010

\begin{tabular}{|c|c|c|c|c|}
\hline \multirow{2}{*}{\multicolumn{2}{|c|}{ Characteristics }} & \multirow{2}{*}{$\begin{array}{c}2008(n=92) \\
n(\%)\end{array}$} & \multirow{2}{*}{$\begin{array}{c}2009(n=95) \\
n(\%)\end{array}$} & \multirow{2}{*}{$\begin{array}{c}2010(\mathrm{n}=115) \\
\mathrm{n}(\%)\end{array}$} \\
\hline & & & & \\
\hline \multirow[t]{3}{*}{1.} & Gender & & & \\
\hline & Female & $39(42)$ & $41(43)$ & $35(30)$ \\
\hline & Male & $53(58)$ & $54(57)$ & $80(70)$ \\
\hline \multirow[t]{5}{*}{2.} & Age at admission, days & & & \\
\hline & $0-3$ & $55(60)$ & $68(72)$ & $81(70)$ \\
\hline & $4-7$ & $12(13)$ & $11(12)$ & $11(10)$ \\
\hline & $8-28$ & $22(24)$ & $15(16)$ & 22 (19) \\
\hline & $>28$ & $3(3)$ & $1(1)$ & $1(1)$ \\
\hline \multirow[t]{5}{*}{3.} & Birth weight, grams & & & \\
\hline & $1000-2500$ & $30(33)$ & $29(31)$ & $20(17)$ \\
\hline & $2501-4000$ & $57(62)$ & $62(65)$ & $88(77)$ \\
\hline & $4001-4500$ & $3(3)$ & $2(2)$ & $4(4)$ \\
\hline & $>4500$ & $2(2)$ & $2(2)$ & $3(3)$ \\
\hline \multirow[t]{3}{*}{4.} & Method of delivery & & & \\
\hline & Vaginal & $71(77)$ & $66(70)$ & $99(86)$ \\
\hline & Caesarean section & $21(23)$ & $29(31)$ & $16(14)$ \\
\hline \multirow[t]{7}{*}{5.} & Length of hospital stay & & & \\
\hline & $0-24 \mathrm{hrs}$ & $18(20)$ & $11(12)$ & $12(10)$ \\
\hline & $25-48$ hrs & $11(12)$ & $5(5)$ & $9(9)$ \\
\hline & $2-7$ days & $34(37)$ & $35(37)$ & $47(41)$ \\
\hline & $8-14$ days & $19(21)$ & $29(31)$ & $28(24)$ \\
\hline & 15 - 30 days & $8(9)$ & $13(14)$ & $15(13)$ \\
\hline & $>30$ days & $2(2)$ & $2(2)$ & $4(4)$ \\
\hline \multirow[t]{5}{*}{6.} & Clinical outcome & & & \\
\hline & Discharged alive & $56(61)$ & $63(66)$ & $85(74)$ \\
\hline & Died $<24$ hrs & $13(14)$ & $6(6)$ & $10(9)$ \\
\hline & Died $24-48$ hrs & $4(4)$ & $4(4)$ & $6(5)$ \\
\hline & Died > 48 hrs & $19(21)$ & $22(23)$ & $14(12)$ \\
\hline
\end{tabular}

\section{Discussion}

The yearly percentages of congenital malformations in our neonatal unit were $13.1 \%$ (2008), $12.2 \%$ (2009) and 14\% (2010) of admitted patients. During that period, the yearly numbers of live births in our hospital were 2,478 (2008), 2,524 (2009), and 2,702 (2010). All 302 infants with congenital malformations presented with clinical manifestations in the first few days of life. We did not include patients with malformations that do not usually manifest in the first few days of life, such as malformations of the urinary tract, and some types of congenital heart defects. Similar to other reports, 0.6 to $1.0 \%$ of our cases required surgical intervention. $3,5,6$

It is interesting to note that the distribution of congenital malformation types was similar in the 3 -year period. As shown in Table 1, the largest proportion of congenital malformations were anorectal defects, with 23\% in 2008, 21\% in 2009 and 26\% in 2010. We also observed a trend of increased cases of
Hirschsprung's disease in 2010. This phenomenon was also observed in Yogyakarta where the most common malformation was Hirschsprung's disease. ${ }^{7}$ In contrast, Turkish studies by Tomatir et al. ${ }^{8}$ and Oztarhan et al. ${ }^{9}$ reported central nervous system malformations to be most commonly found, followed by cleft lips and palate, musculoskeletal malformations, and chromosomal anomalies. These malformations were similar to those observed in Iran, ${ }^{10,11}$ which were markedly different to those in Yogyakarta and Riau. Taksande et al. ${ }^{12}$ in India reported that cardiovascular defects were the most common congenital malformations in liveborn infants, but others reported that malformations of the central nervous system were predominant. ${ }^{13,14} \mathrm{Ge}$ netic and environmental differences between regions may explain the occurences of these congenital malformations, but the specific reasons were unknown. ${ }^{15}$ Furthermore, we are unable to explain the increased prevalence of Hirschprung's disease in Indonesia.

During the 3-year period, we observed a trend in increased number of infants with congenital 
malformations discharged alive, $61 \%$ in $2008,66 \%$ in 2009 , and $74 \%$ in 2010 . This trend may be due to improved patient care, especially the better quality human resources and hospital facilities.

We observed that male subjects outnumbered females at a ratio of $1.6: 1(187 / 115)$. From 2008 to 2010, of 8053 live births in our hospital, 53.4\% were male and $46.6 \%$ were female. Other studies have also noted that more males than females have congenital malformations, especially those with digestive tract malformations. ${ }^{2}$

Most congenital malformation cases were admitted from other health facilities at the age of $0-3$ days. In the past several years there have been efforts to improve the referral system between our hospital and other hospitals/primary health care facilities. These early referrals indicate the success of outside health care providers in early recognition of the malformations, along with rapid referrals leading to potential early intervention.

In our unit, most early surgical interventions were for patients with respiratory problems, while cases with other malformations were only intervened electively (data not shown). We also observed that most infants with congenital malformations admitted to our unit were of normal weight (2500-4000 grams) and delivered vaginally, similar to the prevailing birth weight and delivery methods in our community.

Interestingly, payment methods differed between 2008 and 2009-2010. In 2008 most patients paid the hospital bills out-of-pocket, while in 2009-2010 the majority of patients paid by government subsidy. This observation is evidence of increased government subsidization of health care in the Riau province.

Though not necessarily representative of the province, our study revealed the problems of infants with congenital malformations. Much should be done to improve the situation, including pre-marital counseling, prenatal diagnosis, genetic counseling, and better medical facilities and expertise.

In summary, over the 3 -year period we observed that $13 \%$ of all neonatal unit admissions had congenital malformations. Most patients were referred from other health facilities at an age of $0-3$ days, had normal birth weight, and were delivered vaginally. The most commonly found congenital malformations were digestive tract defects. The types of congenital malformations were relatively constant over time, but there was an increase in the proportion of patients who were discharged alive. It is important for health care workers to have knowledge of congenital malformation types that commonly occur in order to anticipate the conditions and better prepare for the needed facilities in the future.

\section{References}

1. Kalter H, Warkany J. Medical progress. Congenital malformations: etiologic factors and their role in prevention (first of two parts). N Engl J Med. 1983;308:424-31.

2. Stringer MD, Sugarman I, Smyth AG. Congenital defects and surgical problems. In: Rennie JM, editor. Roberton's textbook of neonatology. $4^{\text {th }}$ ed. London: Churchill Livingstone; 2005. p. 711-38.

3. Luks FI. Neonatal surgery. In: Oh W, editor. Evidence-based handbook of neonatology. New Jersey: World Scientific; 2011. p. 439-64.

4. International Statistical Classification of Diseases and Related Health Problems 10th Revision (ICD10) Version for 2007 [cited October 2011]. Available from: http://apps.who. int/classifications/apps/icd/icd10online2007/

5. Lawn JE, Cousens S, Zupan J, Lancet Neonatal Survival Steering Team. 4 million neonatal deaths: when? where? why? Lancet. 2005;365:891-900.

6. Perinatal Mortality Study Group. Perinatal mortality rate - hospital based study during 1998-2001 at Hacettepe University. J Perinat Med. 2003;31:435-40.

7. Wiziyanti E. Angka kejadian congenital malformations di RSUP DR. Sardjito Yogyakarta tahun 2004 - 2007 [cited 2011 October 17]. Available from: http://etd.eprints.ums. ac.id/4015/

8. Tomatir AG, Demirhan H, Sorkun HC, Koksal A, Ozerdem F, Cilengir N. Major congenital anomalies: a five-year retrospective regional study in Turkey. Genet Mol Res. 2009;8:19-27.

9. Oztarhan K, Gedikbasi A, Yildirim D, Arslan O, Adal E, Kavuncuoglu S, et al. Prevalence and distribution of congenital abnormalities in Turkey: differences between the prenatal and postnatal periods. Congenit Anom. 2010;50:221-5.

10. Jehangir W, Ali F, Jahangir T, Masood MS. Prevalence of gross congenital malformations at birth in the neonates in a tertiary care hospital. APMC. 2009;3:47-50.

11. Abdi-Rad I, Khoshkalam M, Farrokh-Islamlou HR. The prevalence at birth of overt congenital anomalies in Urmia, 
Dewi Anggraini Wisnumurti et al: Congenital malformations in the neonatal unit of Arifin Achmad Hospital, Pekanbaru

Northwestern Iran. Arch Iran Med. 2008;11:148-51.

12. Taksande A, Vilhekar K, Chaturvedi P, Jain M. Congenital malformations at birth in Central India: a rural medical college hospital-based data. Indian J Hum Genet. 2010;16:159-63.

13. Singh A, Gupta RK. Pattern of congenital anomalies in newborn: a hospital based prospective study. JK Sci.
2009; 11:34-6.

14. Swain S, Agrawal A, Bhatia BD. Congenital malformations at birth. Indian Pediatr. 1994;31:1187-91.

15. Jackson FL. Human genetic variation and health: new assessment approaches based on ethnogenetic layering. $\mathrm{Br}$ Med Bull. 2004;69:215-35. 